\title{
A topologia dos fluxos aéreos de passageiros entre Brasil e Argentina (2000-2019)
}

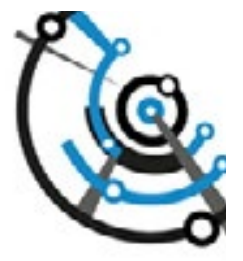

\section{(1) Lucas Azeredo Rodrigues \\ Programa de Pós-Graduação em Geografia, UFSC, Florianópolis, Brasil. ORCID: https://orcid.org/oooo-0001-6925-2730}

Recibido: 11 de enero de 2021. Aceptado: 5 de junio de 2021.

\begin{abstract}
Resumo
O transporte aéreo assume um papel fundamental nos sistemas de movimento dos territórios, haja vista que ele pode expressar diferentes formas de circulação e distintos níveis de interações espaciais. Este texto objetiva analisar a rede de transporte aéreo de passageiros que interliga o Brasil e Argentina, sua evolução entre 2000 e 2019, organização e diferentes formas de estratégias logísticas, sob a perspectiva da Geografia da Circulação, Transporte e Logística. Ao analisar os fluxos aéreos entre tais países, destacam-se diferentes estratégias logísticas adotadas pelas companhias, assim como diferentes níveis de interações socioeconômicas, com destaque para o fluxo turístico.
\end{abstract}

Palavras-chave: Transporte Aéreo; Brasil; Argentina; Geografia da Circulação, Transporte e Logística; fluxos turísticos.

\section{The topology of air passenger flows between brazil and argentina (2000-2019)}

\begin{abstract}
Air transport assumes a fundamental role in the movement systems of territories, given that it can express different forms of circulation and different levels of spatial interactions. This text aims to analyze the passenger air transport network that interconnects Brazil and Argentina, its evolution between 2000 and 2019, organization and different forms of logistical strategies, from the perspective of the Geography of Circulation, Transportation and Logistics. By analyzing the air flows between such countries, different logistical strategies adopted by the companies are highlighted, as well as different levels of socioeconomic interactions, with emphasis on the tourist flow.
\end{abstract}




\section{Introdução}

A Geografia é uma ciência capaz de estudar as múltiplas interações que ocorrem na superfície terrestre por intermédio da sociedade. Significa compreender a forma como a sociedade está organizada e suas interações entre sistemas de objetos e ações. E é a partir da organização espacial que se manifesta o trabalho social, o qual a partir da segunda natureza, expressa os meios de produção e reprodução do capital (Corrêa, 1987).

Santos (2017:268) entende que, "no processo global da produção, a circulação prevalece sobre a produção propriamente dita, os fluxos se tornam mais importantes ainda para a explicação de tal situação". A partir das topologias das redes geográficas, é possível evidenciar a espacialidade humana, da qual uma infinidade de aspectos envolve o fluxo de informações, pessoas, mercadorias, capital, dentre outros (Corrêa, 2018).

Logo, a diferenciação espacial emerge como um questionamento, pois surge como uma problematização diante dos diferentes contrastes no espaço geográfico (Corrêa, 2006), e, por conseguinte, expressa a seletividade territorial, sobretudo quanto aos sistemas de movimento (Santos, 2017). "Assim, os lugares dotados dessas infraestruturas serão mais disputados entre as empresas que entram no jogo da competitividade" (Arroyo, 2015: 42). Como reflexo, é notório perceber o papel de concentração e centralização do transporte aéreo no Brasil, como ressaltado por Silveira e Rodrigues (2020). Isso manifesta uma gama de interações representativas da hierarquia do poder sobre os territórios. Geralmente, esses lugares estão aptos à intensificação dos fluxos materiais e imateriais, e, consecutivamente, propícios a uma maior acumulação de capital.

Diante da recente reestruturação econômica do país, sobretudo a partir do crescimento econômico proporcionado pelo Governo Lula da Silva (2003-2010), é visível que as políticas de desenvolvimento territorial estão diretamente correlacionadas às estratégias logísticas do Estado e das corporações (Silveira, 2019). Por sua vez, é necessário ressaltar que os meios de transporte são fundamentais para a intensificação das dinâmicas socioeconômicas nos territórios, pois as ações da sociedade ao se deslocar, "são determinantes geográficas da produção e reprodução social e, por isso, produzem espaço" (Silveira, 2019:24-25). Blanco (2015:15) ressalta que "las relaciones territorioredes-circulación planteen importantes cuestiones para la compreensión de la dinámica territorial actual".

Dos países que possuem ligações diretas com o Brasil, a Argentina apresenta o maior montante de passageiros. Ao averiguar os fluxos que integram (ou não) o território brasileiro e argentino, observa-se que há momentos de centralização das operações, de aumento da densidade dos fluxos, ao mesmo tempo em que se verifica uma variação dos fluxos que fogem de uma possível regularidade (oferta de destinos).

Daí se questionar: Por que a rede de transporte aéreo que interliga Brasil e Argentina possui um caráter de maior densidade entre Buenos Aires e Rio de Janeiro-RJ/ Guarulhos-SP? Por que nos últimos anos foi possível observar uma maior atuação das empresas em voos diretos entre as principais capitais brasileiras e a Província de Buenos Aires? Quais são as estratégias logísticas dessas empresas? Por que tais pares de origem-destino?

Trata-se de questões complexas a serem desenvolvidas neste trabalho, vez que envolvem dialética entre sistemas de ações e objetos, os quais expressam parte de suas dinâmicas através das interações espaciais, ou melhor, dos fluxos. Estes, que para Corrêa (2018:51), "são intensos e diferenciados qualitativa e quantitativamente, envolvendo informações, capital, pessoas e mercadorias". Ora, a existência de um voo regular de passageiros propicia a exploração de uma infinidade de temas que podem estar correlacionados 
com as dinâmicas territoriais envolvidas nessa circulação entre a saída e chegada dos voos, principalmente quando se diz respeito ao turismo.

Ao observar a série histórica da movimentação de passageiros entre o território brasileiro e argentino, observa-se que o fluxo aumentou aproximadamente 2,5 vezes entre 2000 e 2019, assim como houve uma predominância das operações pelas empresas brasileiras. Todavia, ocorreu uma considerável alteração nos voos com a inserção de novos pares de origem e destino, sobretudo de voos charters na alta temporada, o que pode evidenciar o fomento de novas dinâmicas socioeconômicas.

Logo, há necessidade de compreender o processo de formação socioespacial (Santos, 1977) dos territórios envolvidos, levando-se em conta as múltiplas interações que colaboram para a organização do territorial. Atrelada a esse meta-conceito, adotamos a percepção contida em Silveira (2011) da Geografia da Circulação, Transporte e Logística, capaz de nos direcionar na análise do movimento circulatório do capital via os meios de transporte.

O objetivo deste trabalho é analisar a recente reestruturação do transporte aéreo de passageiros, com o foco nas estratégias logísticas adotadas pelas empresas que operaram voos entre o Brasil e Argentina entre 2000 e 2019. O foco da pesquisa se concentra nas formas de uso do território das empresas aéreas nesses países. Trata-se de um estudo de caso, numa tentativa de contribuir para as temáticas afins. O texto aponta possíveis assuntos que podem ser explorados a partir do turismo entre os países em questão e outros temas como integração territorial e desenvolvimento regional.

Esta pesquisa conta com a elaboração de gráficos e representações cartográficas como forma de auxiliar na interpretação dos fluxos, com dados captados da Agência Nacional da Aviação Civil - ANAC do Brasil. A espacialização desses números leva em consideração todos os voos de passageiros que tiveram entre o Brasil e Argentina. Ainda assim, o recorte temporal desta pesquisa começa em 2000, quando há um direcionamento de uma reestruturação no setor (já mencionada) e se encerra em 2019 devido à questão da disponibilização de dados pelos órgãos reguladores. Adota-se ainda um período quinquenal na cartografia, haja vista que o recorte permite destacar as principais reconfigurações dos fluxos durante o intervalo temporal.

Logo, temos como recortes: temático, o transporte aéreo de passageiros; espacial: o Brasil e a Argentina; e temporal, de 2000 a 2019. Para isso, este texto divide-se em três momentos: 1) um breve debate teórico-metodológico; 2) análise das principais estratégias das companhias aéreas que operaram entre 2000 e 2019 entre Brasil e Argentina; 3) desenvolvimento do fluxo de passageiros entre esses países no mesmo período.

\section{Redes geográficas e fluxos de transporte: formas de compreensão a partir do território e da circulação}

Por intermédio da Geografia dos Transportes são expressos elementos fundamentais para a análise do espaço geográfico, como a circulação, movimentos, fluxos, redes, dentre outros. A dialética movimento-espaço leva em consideração três elementos espaciais: "En primer lugar, las redes de transporte, su estructura y organización espacial. En segundo lugar, la demanda espacial de los servicios de transporte. Por último, los sistemas surgidos em la compleja dialéctica redes-demanda-espacio" (Pons e Reynés, 2004:36).

Santos (2013) assinala que a reconfiguração do território por intermédio de suas funções decorre de um sistema técnico contemporâneo hegemônico, o que atende às 
exigências do mundo globalizado. Sendo assim, os meios de transporte, sobretudo o aéreo, permite-nos extrair informações relevantes sobre diferentes formas de organização territorial a partir da constituição de suas redes geográficas. É o que Silveira (2019) chama de Logística de Estado e Logística Corporativa, destacando que a primeira volta-se para as ações estatais, sobretudo via pactos normativos e demais ações de planejamento territorial; já a segunda, como um conjunto de práticas e estratégias competitivas adotadas pelo meio empresarial, objetiva a redução de custos e otimização dos sistemas de transporte.

Vale destacar a reestruturação do transporte aéreo na América Latina no início do século XXI, que, ao adotar novos modelos estratégicos, colaborou para uma reconfiguração dos fluxos, e, consecutivamente, reorganização territorial do modal. Na verdade, entender a rede de circulação que envolve Brasil e Argentina perpassa pela problematização da evolução (ou não) dos fluxos aéreos entre tais países. Aredes e Silveira (2011:270271) destacam a importância dos fluxos turísticos como uma forma de entender as relações socioeconômicas entre os territórios a partir do setor aéreo, asseverando que "a aviação cresce atendendo também às demandas corporativas do sistema turístico e em sua estratégia competitiva está a parceria com os meios de hospedagem, restauração e mobilidade local." Trata-se daquilo que Rangel (2005), baseado no keynesianismo (movimento circular), chama de efeito multiplicador gerado a partir da implementação e operacionalização de infraestruturas e seus impactos no território.

Para a compreensão do presente torna-se fundamental reconstituir a história da rede geográfica (Santos, 2017), sendo importante acentuar que, a partir da problemática construída sobre determinada rede, "serão selecionados os aspectos a serem analisados. Assim, os agentes sociais podem ser analisados vendo-se para cada uma a função, a frequência dos fluxos, a forma da rede" (Corrêa, 2018:55). Trata-se de resgatar a percepção dialética de Estrutura, Processo, Função e Forma trabalhada em Santos (2018), a fim de evidenciar categorias para análise do espaço geográfico. E um elemento que constitui o elo nessa perspectiva é a circulação por intermédio das redes geográficas, pois

As redes geográficas, como qualquer construção social, são passíveis de análise segundo diferentes dimensões. Sugerimos que três dimensões básicas e independentes entre si, cada uma delas incluindo temas pertinentes para análises específicas, podem descrever a complexidade da rede geográfica: a organizacional, a temporal e a espacial, envolvendo a estrutura interna, o tempo e o espaço. No que tange à dimensão organizacional, sugeriu-se que se considerassem os agentes sociais (Estado, empresas, instituições e grupos sociais), a origem (planejada ou espontânea), a natureza dos fluxos (mercadorias, pessoas, informações), a função (realização, suporte), a finalidade (dominação, acumulação, solidariedade), a existência (real, virtual), a construção (material, imaterial), a formalização (formal, informal) e a organicidade (hierárquica e complementaridade). A dimensão temporal, por sua vez, envolveria o conhecimento da duração (longa, curta), da velocidade dos fluxos (lenta, instantânea) e da frequência (permanente, periódica, ocasional). Finalmente, a dimensão espacial abrangeria o conhecimento da escala (local, regional, nacional, global), da forma espacial (solar, dendrítica, circuito, barreira) e das conexões (interna e externa) ${ }^{1}$ (Corrêa, 2018:55).

Raffestin (1993) destaca que as redes são formas de expressão dos modos de produção, assim como as relações de poder. Ou seja, a "economia e política, técnica e norma, constituem instâncias ou dimensões necessárias para ter a circulação, as redes, enfim 
o movimento" (Arroyo,2015:43). O interesse pelo controle do território deve partir do Estado, haja vista que ele é capaz (ou tem obrigação) de manter o equilíbrio do jogo de poder. Por outro lado, as grandes corporações visam no bojo de suas estratégias competitivas locais onde é possível ampliar sua forma de capital. Isso significa que há a constituição de redes geográficas, a partir do momento em que o Estado atua como ente regulador e o setor privado como explorador de tais ações. Portanto, traçar a constituição da circulação é um caminho propício para compreender determinadas configurações territoriais.

O Estado assume um papel importante na política de integração territorial a partir do momento em que se adotam diferentes estratégias logísticas, dentre elas, os pactos normativos. Estes são capazes de regular o setor, o qual é gerido pela iniciativa privada e atua conforme previsto em lei ou até mesmo na política nacional imposta no momento. Ora, se em alguns momentos vimos projetos de integração em governos desenvolvimentistas, em outros o jogo de interesse por trás do neoliberalismo faz com que o Estado viabilize às grandes corporações a exploração de recursos sem ao menos se preocupar com o bem-estar social. E aqueles lugares que apresentarem maior fluidez estarão aptos a receber investimentos, implicando na seletividade territorial (Santos, 2017).

A competitividade presente nos lugares é resultado dessa forma de expansão de acumulação de capital das grandes corporações, as quais por intermédio de Estados omissos intensificam a acumulação de capital e a centralização de investimentos. Esses glocalismos, manifestações do capital mundial que são impostos sob o nível local (Swyngedouw, 2018), são capazes de evidenciar que a escala de atuação das grandes corporações está cada vez mais fragmentada pelo território, destacando seu papel no desenvolvimento regional, já que são aqueles agentes os principais responsáveis por gerir, em partes, as dinâmicas territoriais, e por conseguinte, a formação das "ilhas de produtividade" (Brandão, 2019).

Para a difusão da cadeia produtiva permear os diferentes níveis escalares, o sistema de movimento (ações e objetos) deve estar apto a atender a demanda por fluidez nos territórios envolvidos. Para Blanco (2015:26), as redes de circulação garantem a eficácia dos fluxos, pois o "imperativo de la fluidez del mundo contemporâneo está asociado con fuertes transformaciones en el território". A existência de fixos e fluxos geram diferentes configurações de redes, as quais expressam diversos meios da circulação, distribuição e consumo através de suas horizontalidades e verticalidades (Santos, 2014).

Por se tratar de um modal extremamente volátil às oscilações econômicas, carece de investimentos de maior envergadura, que muitas vezes estão atrelados ao capital financeiro internacional. Verifica-se, no entanto, que a operacionalidade de um voo demanda know-how de serviços interligados ao circuito superior e inferior da economia nas hinterlândias aeroportuárias. Tais elementos são capazes de exprimir diferentes dinâmicas aos territórios, em escala muitas vezes regional. Isso justifica, em partes, o papel de concentração de voos nas cidades que possuem destaque na centralidade da rede urbana. Se por um lado há um motivo da real demanda por aquele serviço no par de origem-destino, por outro há também a questão da infraestrutura, do equipamento, do desenvolvimento urbano e regional, e demais elementos que integram ações combinadas (ou não) entre a logística de Estado (como agente regulador e controlador das infraestruturas) e a logística corporativa (como agente explorador da atividade).

Seguindo a lógica do efeito multiplicador, a partir do momento em que o Estado fornece pactos normativos e uma infraestrutura adequada, a logística corporativa se sente atraída pela possibilidade de expansão de suas operações. Com isso, a criação de um voo interligando uma cidade a um hub pode instigar possíveis demandas e, consecutivamente, a inserção de novas cadeias produtivas na região em questão. Isso implica 
não apenas o recolhimento de impostos, mas também a geração de empregos. Uma vez gerada a demanda pelo consumo, a consequência lógica é a busca pela prestação de outros serviços, criando mais empregos e renda. Trata-se de uma nova configuração da divisão territorial do trabalho ${ }^{2}$.

A ampliação da divisão do trabalho e do intercâmbio gera a aceleração do movimento e mudanças mais rápidas na forma e no conteúdo. As diferenças entre lugares que eram antes devidas a uma relação direta entre a sociedade local e o espaço local, hoje apresenta outra configuração, já que se dão como resultado das relações entre um lugar dado e fatores longínquos, vetores provindos de outros lugares, relações globais das quais cada lugar é o suporte. [...] Nem sistemas de objetos apenas, nem sistemas de ações apenas, mas sistemas de objetos que influenciam sistemas de ações, sistemas de ações que influenciam sistemas de objetos, sistemas de objetos e sistemas de ações indissoluvelmente juntos e cuja soma e interação nos dão o espaço total. Quanto mais complexa a divisão do trabalho, maior a diversificação e a complexificação dos objetos e das ações, maior a espessura do subespaço correspondente (Santos, 2014:94).

Portanto, é necessário compreender as estratégias logísticas adotadas pelas companhias aéreas, haja vista que elas são delineadoras das malhas aéreas. A necessidade por ampliação dos lucros forçou as companhias aéreas a adotarem sistemas logísticos que reduzissem os custos, dentre os quais se destaca a centralização e concentração das operações em aeroportos centro de operações (hubs). Tal medida acaba extinguindo os voos de múltiplas escalas e a ociosidade de assentos ao longo do trecho, o que amplia sensivelmente o custo-benefício dos voos além de uma maior oferta de conexões (Silveira e Rodrigues, 2020).

\section{Estratégias logísticas dos fluxos aéreos entre Brasil e Argentina $(\text { 2000-2019) })^{3}$}

No ano de 1991 foi criado o Tratado de Assunção, o qual estabeleceu os pactos normativos regularizando o Mercado Comum do Sul - Mercosul, tendo como objetivo a criação de uma zona de integração de países da América do Sul ressaltando elementos de livre circulação. No setor aéreo, foi um passo fundamental para desburocratização do tráfego de passageiro entre os países membros, dentre eles, Brasil e Argentina. Tanto que no período atual não é necessário o uso de passaporte para trafegar entre os países.

Para Silva (2018), o processo de intensificação das relações entre o Brasil e Argentina via pactos normativos fortaleceu acordos bilaterais. Todavia, o reflexo da formação socioespacial ainda se encontra presente, haja vista que as empresas optaram por atuar em pontos dotados de fluidez. Daí surge a necessidade de uma maior intervenção estatal, com a inserção de investimentos pelos territórios daqueles países. Desse modo, podemos destacar que o transporte aéreo é um provedor, ou melhor, impulsionador, para criação ou fomento de novas dinâmicas territoriais.

2 Todavia, deve ser ressaltado que não se deve "romantizar" a difusão das grandes corporações nessa busca pela acumulação de capital, mas, sim, de propor uma forma de interação justa, a qual preserve o bem-estar social da população e reduza a desigualdade socioespacial. 
Ao observar o fluxo aéreo entre Brasil e Argentina, podemos destacar a constituição das seguintes centralidades aeroportuárias: do lado argentino, Buenos Aires (Aeroparque e El Palomar), Ezeiza, Córdoba, Mendoza, Rosário, Bariloche e Tucumán; do lado brasileiro, Guarulhos-SP, São Paulo-SP, Rio de Janeiro-RJ (Galeão), Florianópolis-SC, Brasília-DF, Porto Alegre-PA, Belo Horizonte-MG (Confins), Curitiba-PR, SalvadorBA, Porto Seguro-BA, Recife-PE, Manaus-AM, Fortaleza-CE, Foz do Iguaçu-PR, Cabo Frio-RJ e Campinas-SP. A maioria dessas cidades têm em comum a atividade turística, evidenciando que parte desses fluxos se intensificam em períodos de alta temporada, isto é, a existência de voos charters (temporários). Entretanto, não se deve excluir o movimento de negócios que há entre os dois países, os quais se somam ao fluxo regular.

No que diz respeito às companhias aéreas que operaram entre o Brasil e a Argentina, observa-se que há um maior montante das empresas brasileiras com $62 \%$ do fluxo aéreo total, seguido de $23 \%$ das argentinas e $15 \%$ de outras estrangeiras. Os voos operados são classificados como não-regulares, regulares e cabotagem ${ }^{4}$.

Para Corrêa (2006:99), "na atual fase do capitalismo são as grandes corporações com múltiplas atividades e localização que desempenham o principal papel na reorganização do espaço". Portanto, a compreensão das principais estratégias logísticas ${ }^{5}$ das empresas aéreas podem auxiliar no entendimento de parte dos fluxos aéreos, uma vez que se trata de "uma combinação dos fins (metas) que a empresa busca e dos meios (políticas) pelos quais ela está buscando chegar lá" (Porter, 1986:16). Assim, para poder indicar, em partes, a topologia das redes em questão, há que se considerar as principais formas de atuação, isto é, o comportamento da empresa diante do mercado, a malha, atuação territorial, frota, marketing, divisão territorial do trabalho, dentre outros elementos. É preciso, contudo, levar em conta as dinâmicas, sobretudo regionais, nos territórios envolvidos.

Vejam-se, a seguir e forma sintética, as principais estratégias adotadas pelas empresas aéreas envolvidas neste estudo que operaram voos regulares entre os dois países entre 2000 e 2019:

» Azul: Atua em mercados regional e corporativo, aeroportos descongestionados; usufrui da demanda reprimida, serviço de bordo diferenciado e forte marketing. Opera voos domésticos, de média-alta densidade, e internacional, com alta densidade. Possui uma frota diversificada entre 9, 70, 118, 174, 214 e até 278 pax. Apresenta maior possibilidade e flexibilidade de crescimento pós-pandemia. Aposta em mercado de média densidade e penetração cautelosa em eixos predatórios para sua expansão. Sobre a ligação entre Brasil e Argentina, em 2018 iniciou-se uma forte expansão a partir dos seguintes hubs: Campinas-SP e Recife-PE, e voos charters na alta temporada, como a partir de Cabo Frio-RJ e Navegantes-SC.

" Avianca: Modelo de atuação híbrida (mescla de low cost com full service). Quando era Oceanair, atuou num regional reprimido (após reestruturação da Rio Sul, Nordeste e Tam). Com a chegada dos jatos e a falência de outras empresas (Transbrasil e Vasp), focou nos estados litorâneos e algumas do centro-oeste brasileiro. Após ser adquirida pela Avianca Holdings, seguiu para o mercado de alta-densidade entre capitais estaduais e algumas regionais até sua falência. Sua frota variou entre aeronaves de 30 a 100 pax (Oceanair) e depois disso focou na padronização de Airbus entre 120,132,146 e 238 pax. Embora haja controvérsias sobre sua falência, a empresa optou por arriscar no mercado internacional de alta competitividade, sem ter um

4 Voos que possuíam escalas antes de seguir para o destino.

5 Ou estratégia competitiva. 
mercado doméstico consolidado (falha semelhante à Transbrasil). Apresentou um fluxo próximo de 6 mil pax a partir de alguns destinos de alta temporada entre janeiro e março, quando ainda era Oceanair no eixo Brasil-Argentina.

" Gol: Iniciou suas operações com o conceito de low cost, low fare, porém não conseguiu implementar efetivamente a "baixa tarifa". Aproveitou a compra da Nova Varig e a demanda deixada por ela, pela Vasp e Transbrasil para sua expansão. Atua em mercados de alta densidade a partir de capitais estudais e regionais, e destinos internacionais na América Latina, sobretudo países vizinhos. Seu modelo de aeronave é o B737, o qual varia entre 148-186 pax, pois a padronização de frota facilita diversos ajustes de malha, embora o mercado regional se encontre com demanda reprimida. A expansão com o B737 max para rotas dos E.U.A. é uma ambição antiga da empresa e fomenta a possibilidade do fluxo Brasil-EUA. Começou operar entre o Brasil e Argentina de forma regular a partir de 2005. Entre 2010 e 2019, apresentou uma movimentação média de 0,5 milhões de pax/ano. Após a aquisição da Varig, ampliou sua malha e atuou na demanda reprimida. Possui maior fluxo entre seus hubs (Galeão e Guarulhos) e Buenos Aires. Nos últimos anos, têm expandido as ligações diretas a partir de capitais do nordeste para a Argentina.

» Latam: Após a fusão entre a Lan e Tam, a empresa se consolidou na integração latina a partir da holding. A atuação híbrida e diversos codeshares são um atrativo para passageiros estrangeiros. A empresa possui um mercado de alta densidade, consolidado tanto no Brasil quanto no Chile, e com atuação em outros países. Estava em franca expansão para o mercado internacional (pré-pandemia), e aos poucos foi deixando o mercado regional. Possui uma frota variada de Airbus, com capacidade de 144, 174, 220 até 348 pax, e widebodies da Boeing, que variam entre 221 e 379 pax. Recentemente (2020) passou a ter codeshares com a Azul, compartilhando voos e evitando a competição direta. Embora vivesse uma crise, a injeção de capital da Delta e da Qatar amenizou a crise proporcionada pela pandemia do coronavírus. Aos poucos está retomando a normalidade. Visa, ainda, à consolidação no mercado latino diante de possíveis entrantes. Vale lembrar que a empresa devolveu várias aeronaves novas durante 2020. Sobre os fluxos entre Brasil e Argentina, obteve um leve recuo após a reestruturação da fusão, retomando o crescimento a partir de 2014, quando chegou a transportar entre 0,7 e 1 milhão de pax/ano. Dos destinos, a maioria está concentrada em Guarulhos-SP e Ezeiza. Todavia, há uma modesta movimentação a partir destes para outros destinos que possuem demanda na alta temporada, como capitais do nordeste brasileiro, e Rosário, Córdoba e Bariloche.

" Tam: Começou a operar como táxi aéreo na década de 1970, vindo a crescer a partir das operações no Sistema de Integração do Transporte Aéreo Regional - SITAR. A Tam inicia suas atividades no mercado regional, e assim como a Avianca/Oceanair, ingressando aos poucos no mercado de alta densidade do Brasil. Com a falência de grandes companhias e a flexibilização do setor, foi uma das mais beneficiadas pela ruptura da aviação regional, o que lhe proporcionou considerável expansão até sua crise em 2010; mais adiante houve a fusão com a Lan. Teve uma reestruturação regional com os fokkers, e ao adquirir os Airbus passou a ter apenas jatos na frota. Isso gerou uma demanda reprimida no regional, uma vez que a empresa deu preferência à ligação entre capitais; buscou sua expansão no mercado internacional de grande demanda, chegando a ter o A330 e A340 para voos intercontinentais. O planejamento dos voos internacionais foi feito com cautela, num momento de franca expansão da aviação nacional. Tal situação restou impulsionada pela demanda reprimida, cuja origem remonta à falência de algumas empresas como a Transbrasil, Vasp e Varig. Sobre os voos na Argentina, as operações focaram no eixo Guarulhos - Ezeiza. Todavia, existiam algumas rotas, sobretudo na alta temporada, que operavam a partir de um desses dois destinos para as principais cidades do outro país. Em 2000, a empresa transportou 1 mil pax no trecho, chegando a $901 \mathrm{mil} \mathrm{em}$ 2010, quando teve início a sua fusão com a Lan. 
» Varig: Durante anos, usufruiu de estreita ligação com forças políticas, sobretudo no período da ditatura militar no Brasil, o que facilitou sua rápida expansão e monopólio de rotas. Com a flexibilização do setor na década de 1990, os serviços caros e luxuosos não conseguiram se manter, até que em 2007 foi comprada pela Gol. A empresa passou por quase todas as fases da aviação brasileira, vindo a se expandir no mercado regional, que, aos poucos, foi deixado de lado, dando início à expansão internacional. A frota da empresa foi mista, inclusive nos seus "anos dourados". Na década de 1970, ao mesmo tempo que tinha o E-110 com capacidade de 15 pax, operava o B747 com até 402 pax. Antes de encerrar as operações, tinha uma frota composta de B737 e B767, o que ainda demonstra uma grande variação. A Varig obteve vários mecanismos de ajuda estatal para suas operações, desde o favorecimento de monopólio a empréstimos e financiamentos. Foi responsável por "levar a bandeira brasileira ao mundo", porém na década de 1980, com a emergência do neoliberalismo e da desregulamentação do setor, a empresa não soube se readequar ao novo mercado imposto. Diferente da prática de hub, a empresa tinha voos diretos ligando as principais cidades de alta temporada entre o Brasil e a Argentina. Destacase que a Varig foi a empresa que obteve maior variedade de pares de origem-destino entre esses dois países. Em 2000, transportou aproximadamente 856 mil pax, antes de ser comprada pela Gol em 2007, movimentou cerca de 292 mil pax em 2006 e 127 mil em 2007, o restante foi sendo agregado àquela.

"Vasp: A empresa, que chegou a ser estatal paulista, assistiu a grandes favorecimentos feitos à Varig, enquanto tinha suas operações limitadas aos mercados de alta densidade no Brasil pelo DAC (Departamento da Aviação Civil). Com o sucateamento de empresas públicas, o neoliberalismo canibalizou ao máximo a empresa, até ser privatizada, porém não conseguiu manter suas operações diante do novo mercado do século XXI e cessou suas operações. A empresa, inclusive, chegou a ter subsidiárias em outros países, como Uruguai, Equador e Bolívia. Nas suas origens regionais focou na ligação com o estado de São Paulo. Aos poucos, sua expansão em território nacional centralizou as operações nas capitais. Com a flexibilização do setor, passou a ter muitas rotas internacionais, sem ao menos ter um mercado doméstico consolidado. Antes de sua falência, praticava voos de múltiplas escalas, alguns centralizados em Brasília. Embora no seu início tenha usufruído da demanda reprimida do DC-3, a penetração em mercado de alta densidade fez com que a empresa adotasse o B737 como principal modelo doméstico. Para o exterior, sobretudo rotas intercontinentais, operava o MD-11 com capacidade de 265 pax. Enquanto estatal, a companhia teve investimentos públicos consideráveis, porém sua privatização marcou seu fim, num período conturbado de reestruturação da aviação nacional. A empresa chegou a transportar 105 mil pax entre os territórios brasileiro e argentino. Os voos eram concentrados em Ezeiza e tinham ligações com Guarulhos-SP e Galeão-RJ de forma regular, e outros destinos da alta temporada como Recife-PE e Florianópolis-SC.

" Aerolíneas Argentinas: Companhia estatal argentina que chegou a ser privada, sendo fundamental ainda hoje para a integração do país. Sua expansão ocorreu quando passou a ter destinos intercontinentais; todavia, demandava no início por várias escalas, inclusive no Brasil, o que reforça a ligação entre esses países. Sua malha concentra voos em Buenos Aires (Aeroparque) e Ezeiza, e conecta as principais cidades do território argentino em atuação conjunta com a Austral. No que diz respeito aos destinos internacionais, a maioria está conectando a Argentina aos demais países da América do Sul, sobretudo ao Brasil. No entanto, possui voos que fazem ligação com a Espanha, México e E.U.A. Na década de 1950 operou majoritariamente os DC-3. Com a chegada dos B737 na década de 1980, a empresa passa a expandir no mercado internacional com os widebodies, dentre eles o B747 e A340. Na recente reestruturação, a empresa focou nos B737 (128-170 pax) e no A330 (272 pax).

" Austral: A companhia “irmã” da Aerolíneas Argentinas transformou-se em empresa pública para manter suas operações regionais, até ser privatizada junto com esta. 
Posteriormente a Argentina implementou um plano de reestatização das empresas aéreas, a partir do que passou a atuar como subsidiária da Aerolíneas. Operou no mercado regional argentino e curtas rotas internacionais de menor demanda, sobretudo fora da alta temporada, como Curitiba-PR e Florianópolis-SC para Buenos Aires. A empresa utilizava aeronaves de média densidade como os MD-80 e DC-9, mas optou por padronizar sua frota com os E-190 num período recente. Possui uma grande flexibilidade de atuação em diferentes mercados de média e alta densidade por causa dos E-190. Em 2014, entrou em operação regular no trecho entre Brasil e Argentina. As principais rotas interligam as capitais da região centro-sul do Brasil, indo em direção a Buenos Aires, Ezeiza, Rosário e Córdoba. Todavia, há a possibilidade de expansão de voos para outros destinos de alta temporada como Foz do Iguaçu-PR e Salvador-BA.

»Dinnar: A empresa se origina fazendo rotas de múltiplas escalas na Argentina na década de 1990. Com a reestruturação de sua malha, chegou a operar rotas charters para o Brasil em direção a cidades litorâneas durante a alta temporada (Florianópolis-SC, Salvador-BA e Porto Seguro-BA), mas também teve voos regulares para Guarulhos-SP. Nos seus últimos anos de atividade, tinha uma frota padronizada com MD-80, para mercados de média densidade. Ao todo, transportou aproximadamente 15 mil pax em 2000 e 2001 entre os dois países.

» FlyBondi: A empresa low cost, low fare iniciou suas operações em 2018 com uma frota de cinco B737 e capacidade para 189 pax. Faz a interligação entre mercados densos na Argentina. A sua expansão inicial contou com a atuação em cidades brasileiras, dentre elas Florianópolis-SC e Rio de Janeiro-RJ (Galeão). Possui como características marcantes a não-linearidade e a volatilidade da malha aérea. Em 2019, movimentou cerca de 14 mil pax entre o Brasil e a Argentina, e, em 2020, 34 mil pax. Há um mercado para a empresa operar, sobretudo o turístico, porém poucos favorecimentos estatais.

» Lan Argentina: Empresa subsidiária do Holding Lan. Operou entre os principais aeroportos do território argentino tendo o Aeroparque (Buenos Aires) como seu hub. Chegou a ter voos internacionais para os E.U.A. e o Brasil. Possuía uma frota variável de A320 e B767. Porém, com a crise do novo coronavírus, a empresa (já como a Latam) encerrou as atividades em junho de 2020. A companhia transportou aproximadamente 2 mil pax entre o Brasil e a Argentina, variando as operações entre 2006 e 2015 com voos pontuais.

Sobre os voos de cabotagem, verifica-se que a maioria se originava na Argentina ou em algum país do exterior, e fazia escala num $h u b$ brasileiro, para depois seguir ao seu destino. Destaca-se que a maioria das empresas operantes desses voos eram de grande expressão mundial, como Air Canada (Canadá), Swiss (Suíça), Condor (Alemanha), Lufthansa (Alemanha), Emirates (Emirados Árabes), Ibéria (Espanha), Copa (Panamá), KLM (Holanda), Air Europa (Espanha). Essas empresas possuíam voos diretos desses países para o Brasil, e faziam uma extensão até Ezeiza, aproveitando a demanda do exterior, e até mesmo a partir do território brasileiro para Argentina. Raros eram os voos (geralmente charters) que se originavam no Brasil e faziam escalas no território argentino ou vice-versa.

Dos voos não-regulares, o destaque segue para companhias aéreas charters ou até mesmo que operam voos regulares em outros países, como a Delta (E.U.A), Aeroméxico (México), Edelweiss (Suíça) e Amaszonas (Paraguai). Porém, aparecem outras empresas características de fretamento como a argentina Andes e a portuguesa Hifly. Das brasileiras em questão, o destaque vai para a BRA, a qual possuía inicialmente a estratégia de servir voos fretados para agências de viagens, inclusive para a Varig.

Para analisar os fluxos aéreos, é importante compreender as estratégias logísticas das companhias que operam no setor. Entretanto, as interações entre os territórios de 
origem-destino refletem, em parte, não apenas a estratégia da companhia, como também as dinâmicas regionais.

A atuação dessas empresas (Figura 1) evidencia uma forma de poder sob o território, através de fluxos intensos e mais ou menos densos de uma divisão territorial do trabalho e de uma hierarquia, expressando diferenciações no espaço geográfico (Corrêa, 2018). Isto significa que, a partir das grandes corporações, novas formas se projetam no espaço geográfico, ressaltando-se o "papel das diversas formas de circulação nessa reorganização da divisão internacional do trabalho, sobretudo no que toca à reorganização espacial. A circulação já não se define como antes, apenas pelos transportes e pelas comunicações" (Santos, 2013:95).

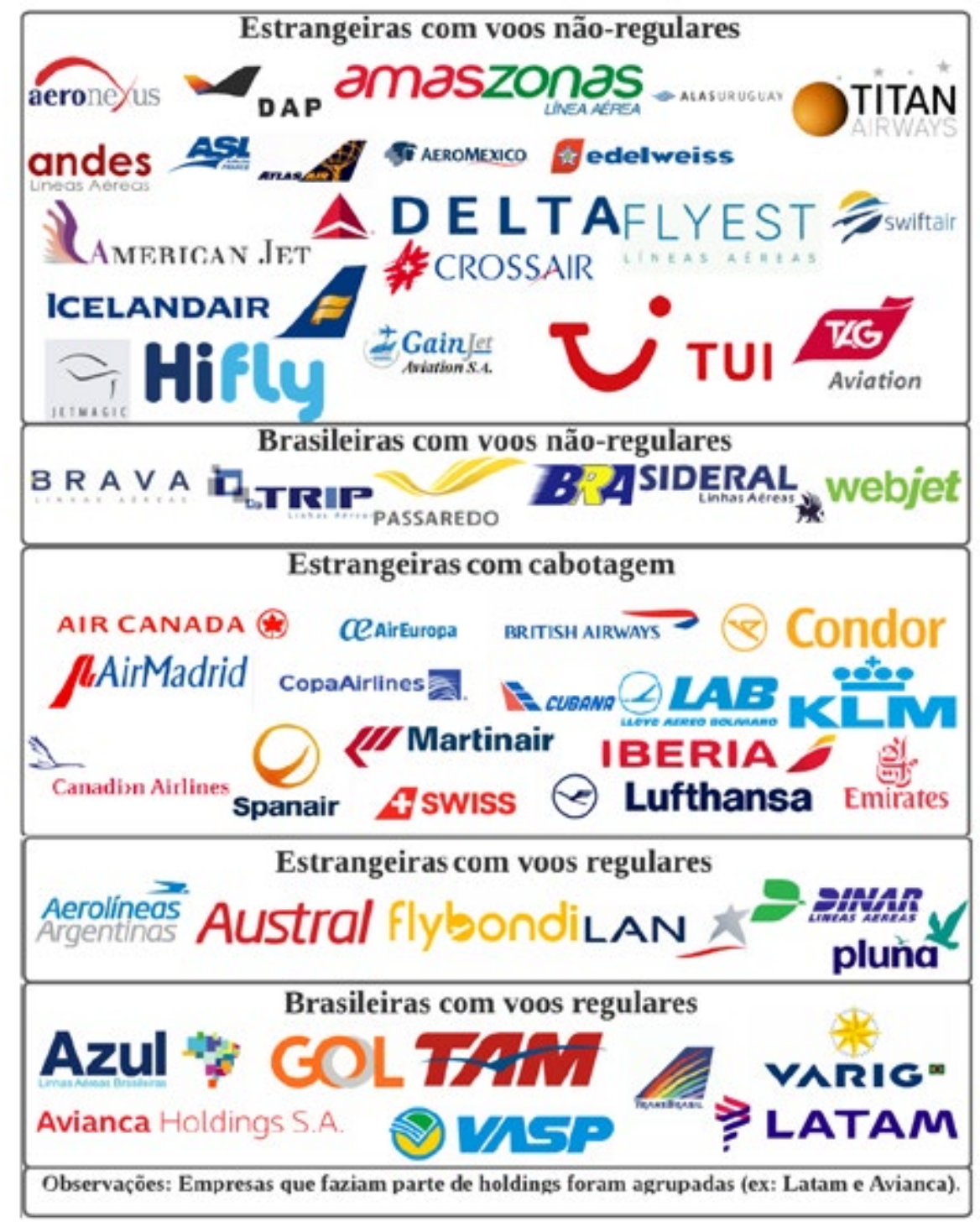

Figura 1. Companhias aéreas que operaram entre o Brasil e a Argentina entre 2000 e 2019. Fonte: ANAC (2020). Elaboração: Autor (2020).

Entende-se que as redes técnicas obedecem a uma hierarquia, a qual está atrelada ao jogo da competitividade territorial. Espaços dotados de fluidez estão mais propícios a intensificarem a circulação de capital: 
Esa selectividad, sin embargo, no es ajena a la historia territorial, ya que las nuevas redes entran en diálogo con las redes preexistentes en un processo que puede ser de reforzamiento, concentración, innovación o conflicto. La selectividad no solo está dada por la incorporación diferenciada al conjunto relacional que toda red implica sino también con la introducción de velocidades diferenciales, que alimentan las desigualdades en el território (Blanco, 2015:19).

Portanto, o estudo da topologia das redes pode auxiliar na análise da configuração territorial. Considera-se que a materialização da circulação evidencia diferentes níveis de atuação de poder do capital. Entender o porquê de a rede geográfica do transporte aéreo possuir tal forma colabora para a construção de políticas públicas que favoreçam uma melhor distribuição dessa prestação de serviço. Tal situação será trabalhada no próximo tópico.

\section{"Por uma geografia do movimento": o fluxo aéreo de passageiros entre o Brasil e a Argentina}

Dados da ANAC (2020) indicam que entre 2000 e 2019, 95\% dos voos operados foram regulares, contabilizando um montante de 49,2 milhões de passageiros diante dos 2,5 milhões não-regulares. Geralmente, estes são voos fretados por agências de turismo, voos extras das companhias regulares e até mesmo fretamentos esportivos ou corporativos. No entanto, para entender a topologia das redes que são expressas pelo transporte aéreo, deve ser considerado múltiplas interações, desde num âmbito regional, pois leva em consideração as diferenciações territoriais

A Figura 2 ilustra a curva de crescimento da movimentação de passageiros entre o Brasil e a Argentina. Embora apresente um crescimento gradual, destacam-se a queda em 2002 e 2009. A primeira, reflexo da crise econômica que assolava partes da América Latina, resultante da fragilidade do neoliberalismo herdado de 1990. Já a segunda, impactos da crise oriunda do colapso do mercado imobiliário especulativo dos E.U.A.

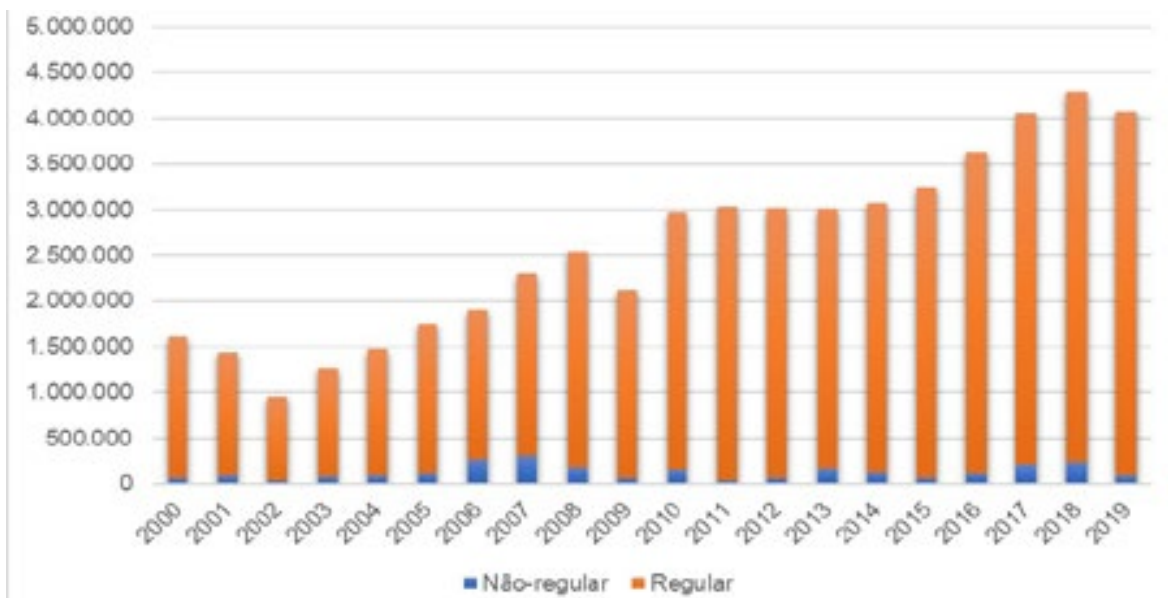

Figura 2. Movimento de Passageiros entre o Brasil e Argentina. Elaboração: Autor (2020). Fonte: ANAC (2020)

As crises afetaram a circulação de pessoas, haja vista que há oscilações do dólar. Ambos os casos foram influenciados por fatores externos, tais como: os impactos na segurança da aviação após os ataques de 11 de setembro de 2001; a crise financeira das companhias 
brasileiras como a Varig; e o frágil processo de privatização da Aerolíneas Argentinas. Todavia, a recuperação econômica do governo de Néstor Kirchner (2003-2007) e de Lula da Silva (2003-2010) funcionaram como estopim da retomada de crescimento, além de permitirem a reestruturação das estratégias logísticas das empresas aéreas.

Já a Figura 3 ilustra o papel da alta temporada de veraneio. O mês de janeiro destoa dos demais, uma vez que o turista argentino sempre busca cidades brasileiras litorâneas, como as capitais nordestinas, Rio de Janeiro-RJ e Florianópolis-SC. Também é visível um pico considerável em julho, este impulsionado pelo turista brasileiro em busca da Patagônia, a Cordilheira dos Andes ou as neves de Bariloche. Entretanto, percebe-se que há pouca variação durante $\mathrm{o}$ ano, e isso ocorre por causa das possibilidades alternativas e do menor custo para viagens, pois a demanda não está alta. Outro fator a ser considerado diz respeito ao período de férias escolares (dezembro, janeiro e julho).

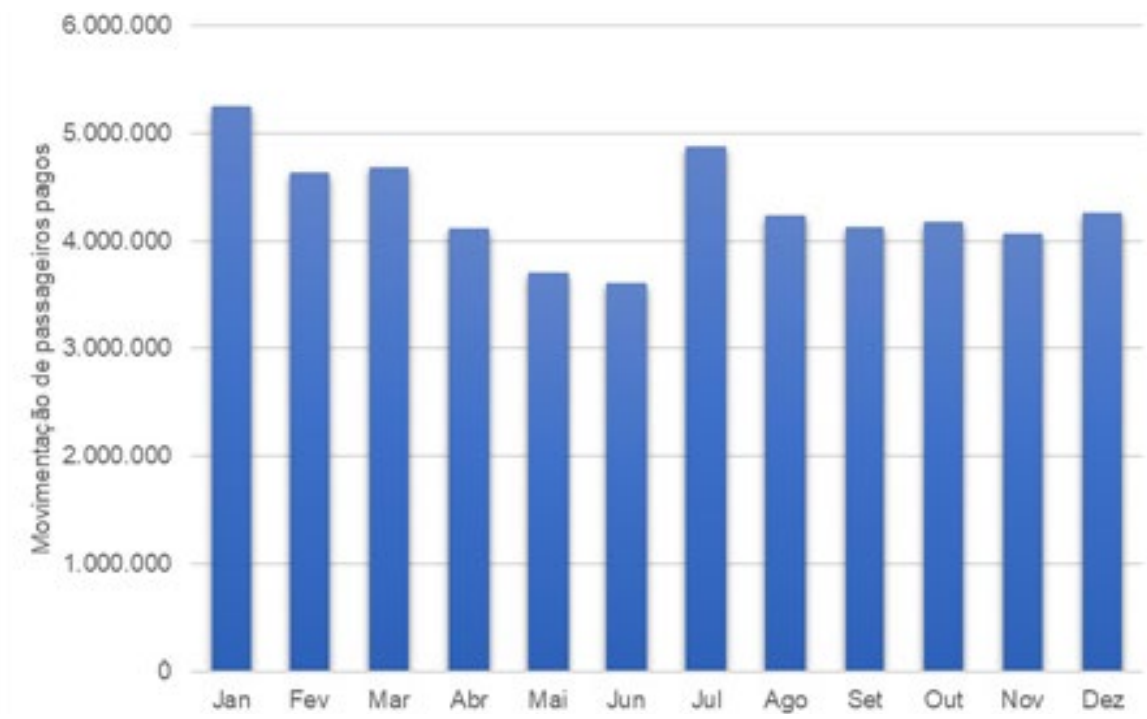

Figura 3. Fluxo de passageiros acumulado por mês entre 2000 e 2019. Elaboração: Autor (2020). Fonte: ANAC (2020).

Tratando do direcionamento dos fluxos, a Figura 4 ilustra os voos que ocorreram entre Brasil e Argentina no ano 2000. Nitidamente, o eixo de maior densidade é GuarulhosEzeiza, os dois principais hubs dos respectivos países. Embora tenha uma relativa densidade a partir de Córdoba, Rosário e Bariloche, Porto Alegre-RS, Florianópolis-SC, Rio de Janeiro-RJ e Salvador-BA também possuem destaque. Apenas o movimento de Ezeiza para Guarulhos e Rio de Janeiro representou 13\% do fluxo internacional em 2000, além dos voos de cabotagem (ANAC, 2021). 


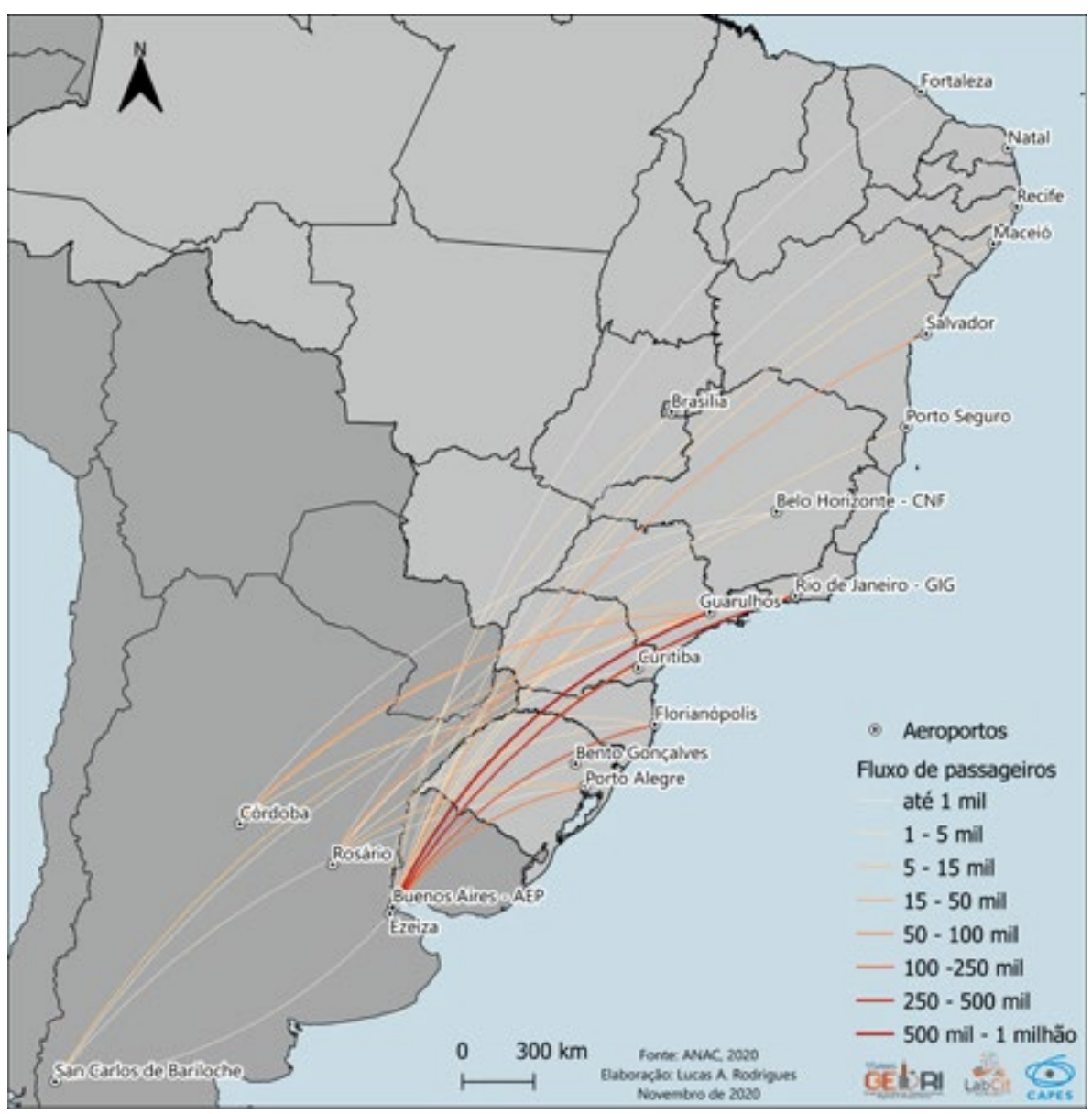

Figura 4. Fluxos aéreos de passageiros entre o Brasil e a Argentina em 2000. Fonte: ANAC (2020). Elaboração: Autor (2020).

Em 2000, das empresas regulares com voos diretos, a Aerolíneas concentrava seus voos a partir de Córdoba e Ezeiza, com ligações deste último para Florianópolis-SC, Guarulhos-SP, Porto Alegre-RS e Galeão-RJ. A empresa também chegou a operar voos de cabotagem em direção a Madrid (Espanha), com escala no Brasil. Em relação às companhias brasileiras, apenas a Varig transportou 856 mil passageiros em direção a Ezeiza e outros destinos argentinos a partir de Guarulhos, como Córdoba, Rosário e Bariloche. Já a Transbrasil e a Vasp, ambas ainda em reestruturação, tentavam avançar no mercado internacional, focalizando a ligação a partir de seus hubs para Ezeiza. Os fluxos de alta temporada interligavam o território argentino a cidades do nordeste brasileiro, como Salvador-BA, Porto Seguro-BA, Foz do Iguaçu-PR, NatalRN, Fortaleza-CE, Recife-PE e no sul, Florianópolis-SC. Em contrapartida, é visível uma movimentação considerável a partir de Córdoba e Rosário (além de Ezeiza), e, de forma tímida, Bariloche.

No ano de 2001, empresas como a Air Canada iniciam voos de cabotagem, operando o trecho Ezeiza-Guarulhos-Toronto. A Varig mantém a soberania no trecho (EZEGRU). Por sua vez, a Transbrasil inicia sua derrocada (assim como a Vasp), vindo a ter sua falência decretada no final desse mesmo ano. A argentina Dinar passa a ter voos a partir Ezeiza, com destino a Porto Seguro-BA e escala em Florianópolis-SC e entre Salta e Guarulhos-SP. Já a Aerolíneas apresenta um recuo, de 416 mil pax em 2000 para 180 mil pax em 2001. No ano seguinte, ela retoma o crescimento, assim como a Dinar aumenta suas opções de destinos, chegando a movimentar 10 mil pax 
na alta temporada. A Varig recua sua movimentação em mais de 300 mil pax e a Tam passa a atuar de forma mais competitiva. No entanto, em 2002 as características dos fluxos se mantêm. O ano de 2003 apresenta uma mudança, com a inserção dos voos de cabotagem da Lufthansa no trecho Ezeiza-Guarulhos, e, em seguida, para a Alemanha, assim como a British na rota Ezeiza-Guarulhos-Londres.

Em 2005 (Figura 5) evidencia-se uma tendência mais centralizadora dos voos entre Ezeiza, Guarulhos-SP e Galeão-RJ, resultado dos impactos da reestruturação do setor aéreo brasileiro, como a redução da oferta de voos para os destinos de alta de temporada, sobretudo nordeste, pois, utilizaria o sistema de conexões a partir dos hubs. Embora a centralização das operações reflita numa redução de custos e ofertas de voos diretos, há um incremento significativo de destinos para o território argentino, sobretudo de movimentação para Bariloche.

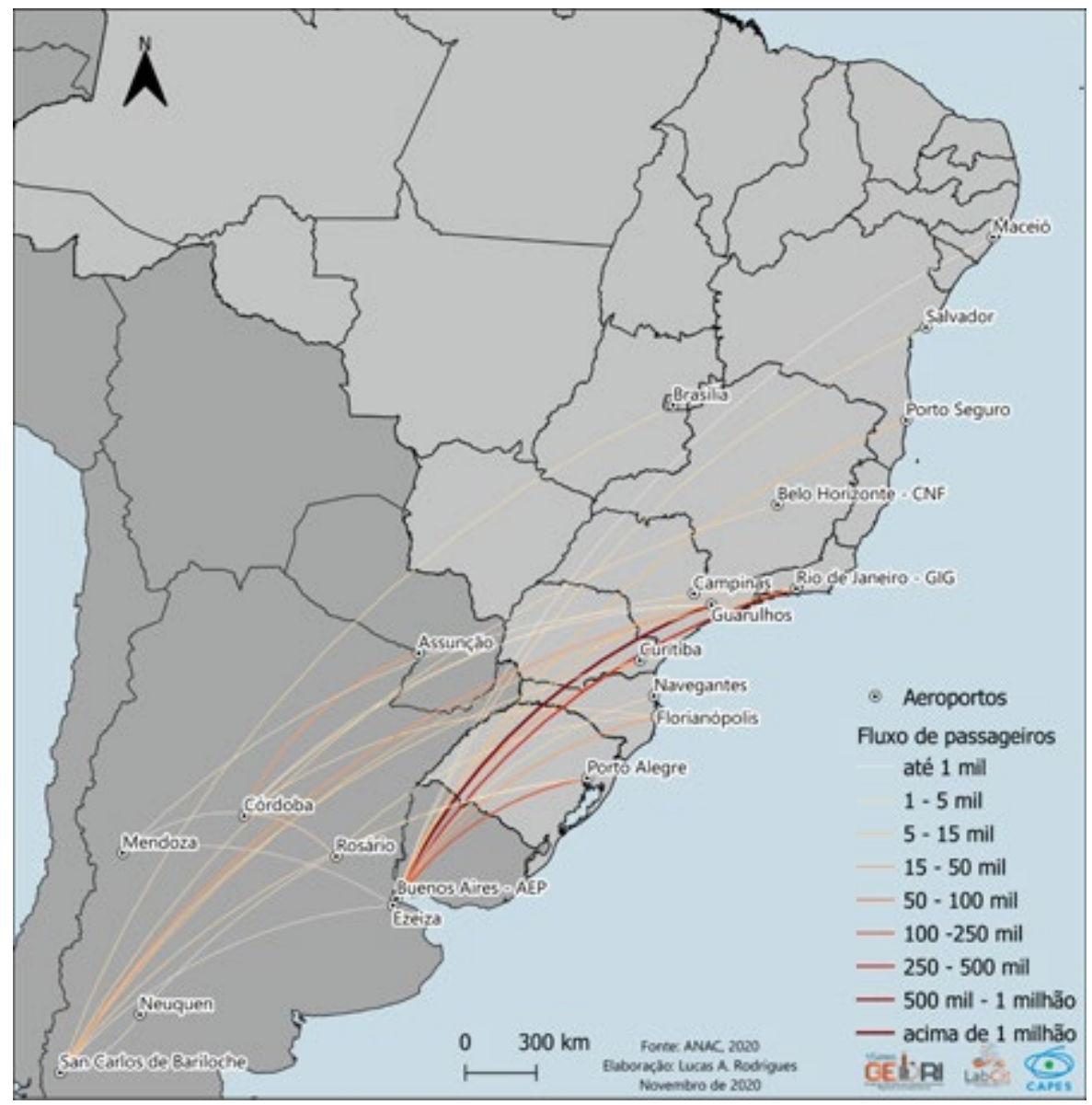

Figura 5. Fluxos aéreos de passageiros entre o Brasil e a Argentina em 2005. Fonte: ANAC (2020). Elaboração: Autor (2020).

A partir de 2005 houve uma reestruturação de diversas empresas. Se por um lado a Varig estava prestes a decretar falência, por outro o crescimento da Tam e da Gol ilustram a configuração do transporte aéreo brasileiro. Companhias aéreas de menor porte, como a BRA e Pluna, tentam investir num mercado agressivo e competitivo, fora do seu nicho de atuação, mas não o suficiente para competir com as empresas maiores. O fluxo para 2007, 2008 e 2009 mantém o padrão médio de crescimento. Contudo, deve-se considerar que a crise de 2009 afetou muito mais forte a Argentina do que o Brasil, uma vez que o Governo Lula (2003-2010) soube 
adotar medidas paliativas para conter o impacto nas dinâmicas socioeconômicas do país, ações que Bielschowsky (2012) define como três frentes do desenvolvimento econômico: o consumo em massa, exploração de recursos naturais e investimentos em Infraestrutura.

Os fluxos de 2010 (Figura 6) elucidam o padrão de densidade dos voos entre hubs. Entretanto, fica evidente uma maior expansão dos pares de origem-destino e a captação de novos mercados com ligações diretas. Vale ressaltar que nem todo o fluxo de Buenos Aires e Ezeiza para Guarulhos-SP e Galeão-RJ significa que houve desembarque em tais destinos, pois, uma vez estabelecida a conexão entre hubs, a gama de conexões é enorme, o que favorece importantes ganhos nas taxas de ocupação. O ano de 2010 representa um momento em que empresas de alto padrão passam a operar o trecho via cabotagem, como o caso da Qatar, que fazia o voo Doha-Guarulhos-Ezeiza. Já a Gol atinge a marca de mais de 1 milhão de pax no entre o Brasil e a Argentina, com destaque para o trecho Guarulhos-Ezeiza, contabilizando aproximadamente 0,5 milhão.

O setor aéreo brasileiro estava num período de transição da fase de ruptura da aviação regional para a formação do segundo oligopólio, pois, além da concentração de mercado após a associação entre Azul e Trip, houve a fusão entre a Tam e a Lan e a aquisição da Webjet pela Gol (Silveira e Rodrigues, 2020). A centralização de capital se torna cada vez mais presente. Os fluxos ficam cada vez mais concentrados e a conexão entre cidades regionais mais escassa. Em contrapartida, a Aerolíneas que havia sido estatizada em 2008 passa por uma intensa reestruturação, identidade visual, renovação de frota e etc.

Para os anos seguintes (2011-2015) a projeção de crescimento na movimentação geral se mantém. Atenção especial para a Austral que em 2012 movimentou cerca de 53 mil pax e passa para 342 mil em 2015. A empresa operou voos em direção ao Aeroparque (Buenos Aires), porém, ao atuar em alguns mercados de baixa/média densidade, como Florianópolis-SC, Confins-MG, Porto Alegre-RS e Curitiba-PR, não competia diretamente com a Aerolíneas. Além disso, a consolidação da holding Latam (Lan, Tam Linhas Aéreas e Tam Mercosur) põe em cheque a possível construção de empresas que atuem de forma conjunta nos países latinos. A inserção da Emirates operando Dubai-Galeão-Ezeiza movimentou entre 111 e 125 mil pax por ano, assim como a Turkish Instanbul-Guarulhos-Ezeiza, transportando entre $4 \mathrm{e}$ 118 mil passageiros. 


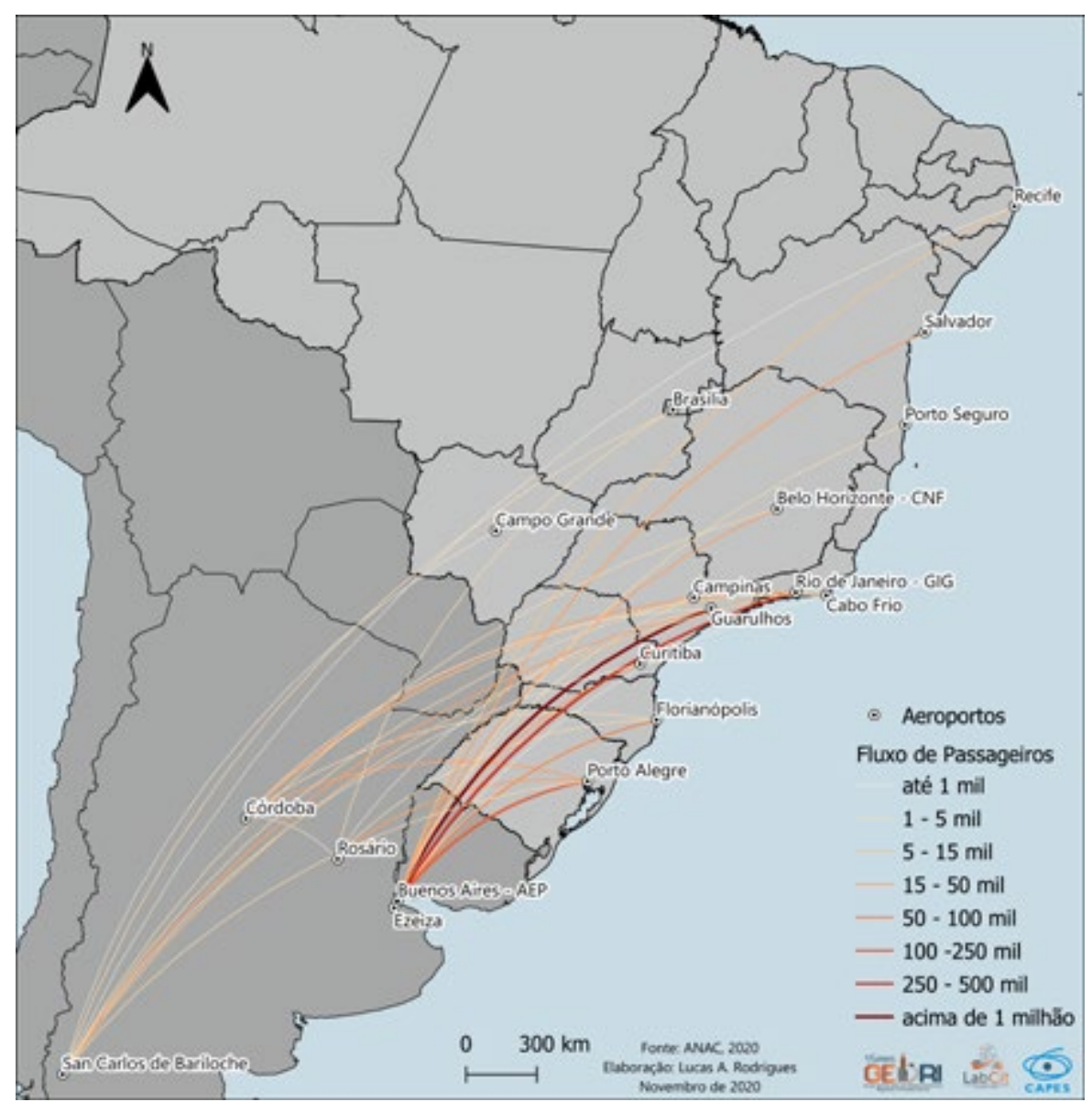

Figura 6. Fluxos aéreos de passageiros entre o Brasil e a Argentina em 2010. Fonte: ANAC (2020). Elaboração: Autor (2020).

Em 2014 o Brasil passava por diferentes conflitos geopolíticos, dentre eles a fragmentação do Governo Dilma (2011-2014 e 2015-2016) ocasionada pelo jogo de interesses da oposição, de fato, "do céu ao inferno em 36 meses" (SINGER, 2015;39). Pelo lado argentino, a crise do governo conservador de Macri (2015-2019) se agravou, resultando na asceção do neoliberalismo, que no Brasil se tornaria a realidade com o Governo Temer (2016-2017).

Com a centralização de capital cada vez mais presente e uma omissão de órgãos regulares (adotando a lógica de Estado mínimo), acirrou-se a competitividade e, cada vez mais, a quantidade de empresas regulares foi reduzindo. Os fluxos de 2015 (Figura 7) mostram o poder de concentração de voos, não apenas do ponto de vista locacional (dos pares de origem-destino), mas também da quantidade de empresas operando entre os dois países. Observa-se que há uma redução significativa dos fluxos inferiores a 1 mil passageiros, o que reforça a ideia das remodelações das estratégias logísticas. 


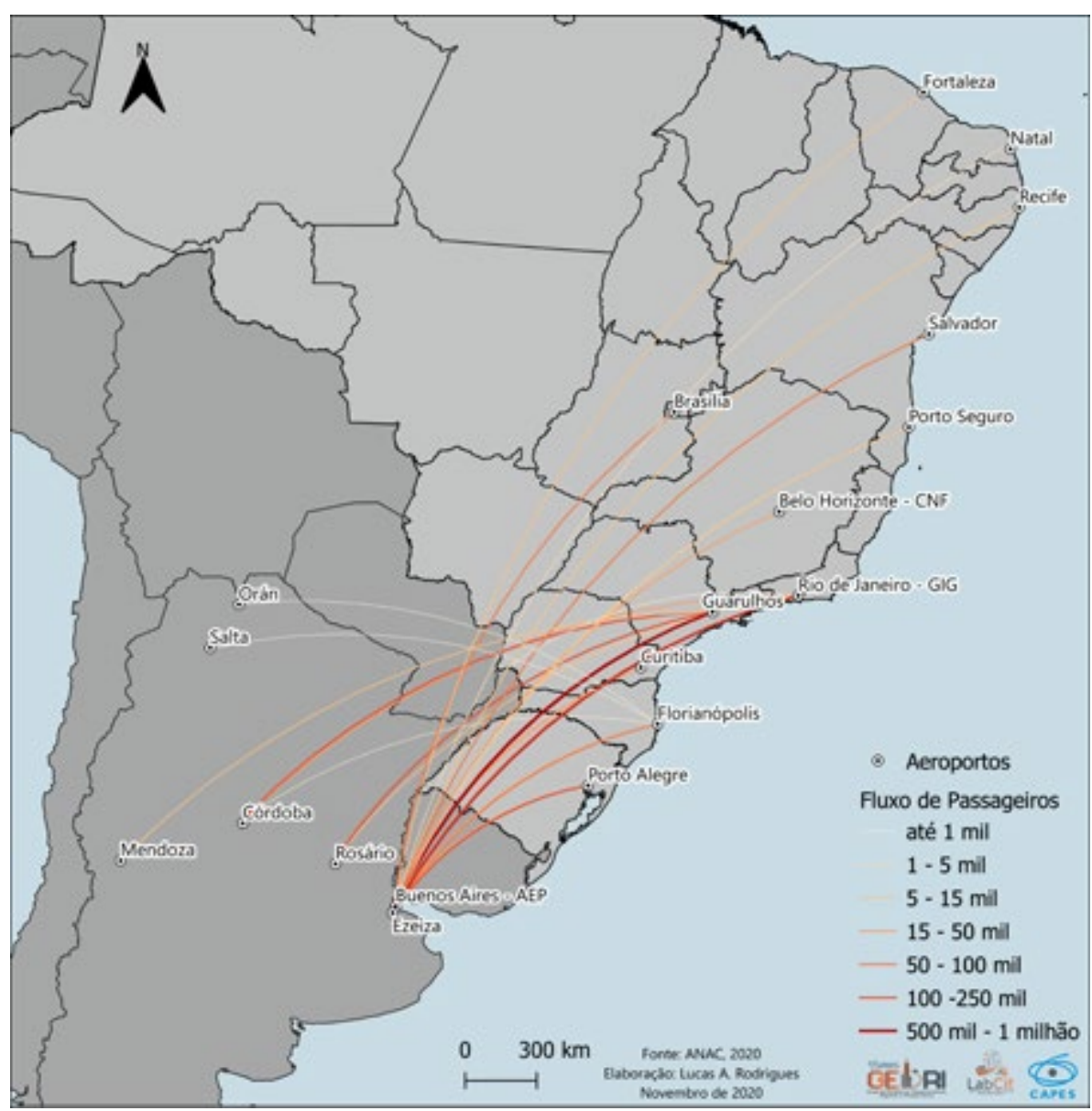

Figura 7. Fluxos aéreos de passageiros entre o Brasil e a Argentina em 2015. Fonte: ANAC (2020). Elaboração: Autor (2020).

Entre 2016 e 2018 o setor aéreo brasileiro assiste à concentração maciça de operações. Centralizado entre a Latam, Gol, Azul e Avianca (com pequenas participações das regionais), a reestruturação do setor diante da formação do segundo oligopólio traz à tona a necessidade de reinvenção das estratégias logísticas. De um lado, a Gol apostou num maior fomento de ligações com países latinos (sobretudo Argentina); de outro, a Avianca insistiu nos voos internacionais de alta competitividade, mas entrou em crise e encerrou as atividades em 2019. Por sua vez, a Latam apostou mais numa integração entre países latinos com voos para os E.U.A e outros continentes; e a Azul, de forma mais concisa e racional, reestruturou o sistema de voos regionais, atuando em mercados reprimidos e gerando sua demanda para voos internacionais. Em contrapartida, na Argentina, a Aerolíneas e a Austral mantiveram o somatório de movimentação aproximada da casa dos 1,1 milhão de pax entre Brasil e Argentina. Veja-se que a movimentação dos fluxos aéreos em 2019 é bem diferente de 2015.

A busca por novos mercados desponta uma competitividade quase que predatória entre as empresas aéreas. É visível a intensificação do uso de outros aeroportos para além do condensado trecho Ezeiza-Guarulhos (e até mesmo para o Galeão). Não que isso signifique melhoras nas economias dos países; ao contrário, a fragilidade do Governo Bolsonaro (2018-atual) evidencia um Estado negligente, assim como o desastre do neoliberalismo de Macri na Argentina. Mas a remodelação logística das empresas aéreas, junto com maior competitividade, auxilia na queda dos preços das passagens, o que ainda se torna um fator atraente na tomada de decisão no planejamento de atividades laborais. 
Em si, a busca por ligações mais diretas tem sido uma saída para o descongestionamento dos hubs, mas também evidencia uma série de elementos relativos à circulação de pessoas e aos fluxos de capital numa escala regional, onde estão localizados os aeroportos em questão. Assim como a Azul usufrui de Confins-MG e Campinas-SP, a Flybondi opera no aeroporto de El Palomar na capital argentina. Entretanto, deve-se considerar o fluxo de negócios, sobretudo aqueles com destino à macrometrópole paulista.

Sobre os destinos no Brasil, veja-se que mais recentemente houve uma maior concentração de voos na faixa litorânea, fomentada pelo turismo de alta temporada, sobretudo nas capitais (que são importantes nós da rede urbana). Fortaleza-CE, Natal-RN, João Pessoa-PB, Maceió-AL, Recife-PE, Salvador-BA, Rio de Janeiro-RJ e Florianópolis-SC são cidades que demandam alta circulação de pessoas durante o verão. Fora das capitais, os destinos são Cabo Frio-RJ, Navegantes-SC e Porto Seguro-BA, sendo que a primeira cidade, atende a região dos lagos no estado fluminense e a segunda, o eixo que permeia Itajaí-SC até os limites da região metropolitana de Florianópolis-SC, com destaque para Balneário Camboriú-SC.

As cidades de Manaus-AM, Foz do Iguaçu-PR, Curitiba-PR, Porto Alegre-RS, BrasíliaDF, Campinas-SP, Guarulhos-SP e Belo Horizonte-MG apresentam um fluxo considerável, sendo que, do ponto de vista turístico, as duas primeiras possuem um maior destaque; as demais são hubs das empresas aéreas, e, pela centralidade de operações, justificam a densidade do trecho. Claro que há outros elementos a serem considerados, sobretudo os corporativos, que demandam circulação para tais cidades, mas não como destino, e, sim, por conexão.

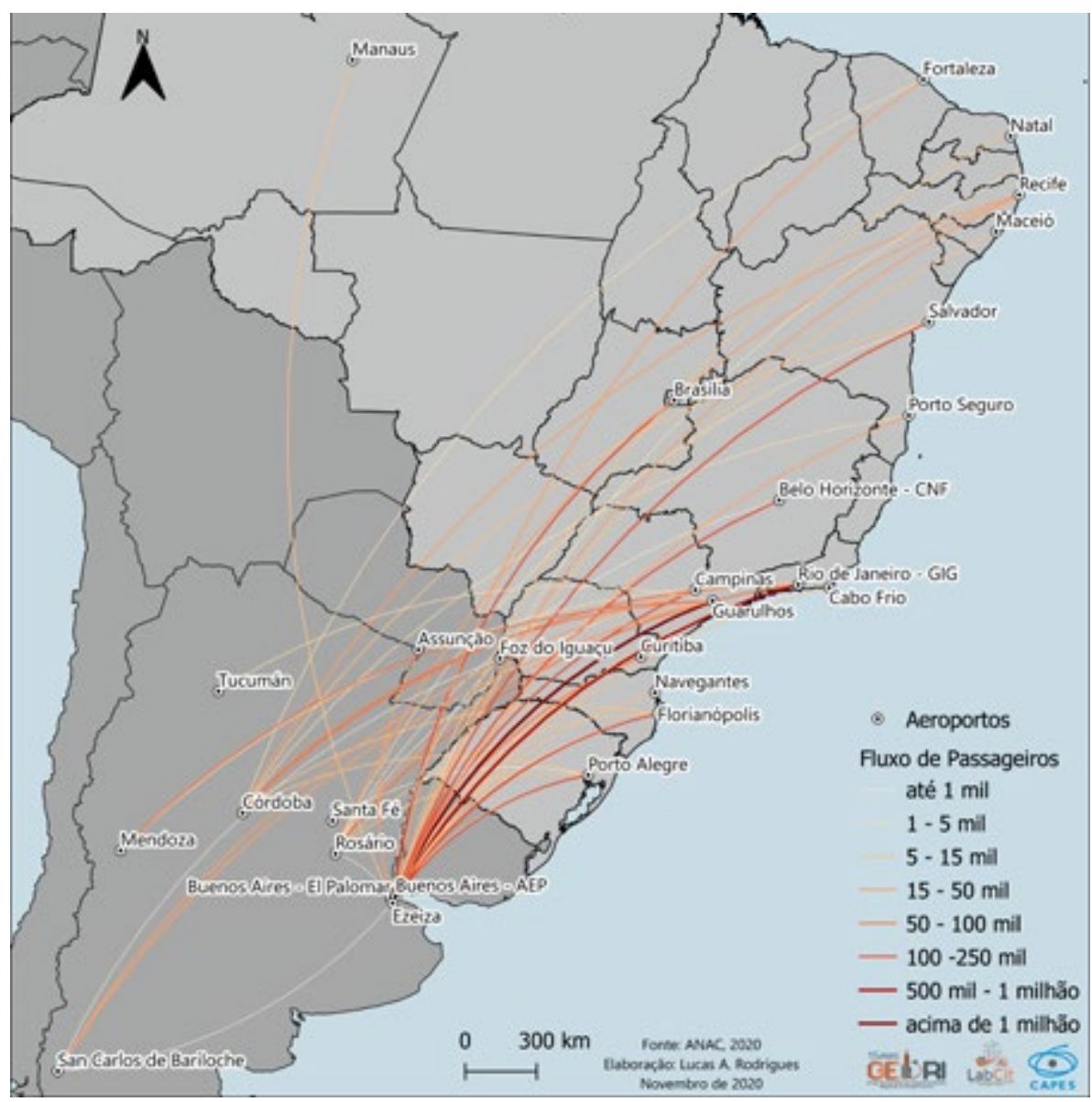

Figura 8. Fluxos aéreos de passageiros entre o Brasil e a Argentina em 2019. Fonte: ANAC (2020). Elaboração: Autor (2020). 
Já na Argentina a maior concentração de voos fica na região da província de Buenos Aires (Aeroparque, El Palomar e Ezeiza). Além da demanda turística, por ser capital, apresenta um volume de negócios considerável na divisão territorial do trabalho argentina. Bariloche, localizada na Patagônia, demanda por um turismo, especialmente no inverno, com a prática de esqui e visitas a paisagens deslumbrantes. Mendoza, quase no Chile, possui uma forte presença de vinícolas e uma mescla de atividades naturais nos Andes com pontos culturais na área urbana. Assim como Córdoba, segunda maior cidade da Argentina, Rosário, Tucumán e Santa fé demandam um turismo mesclado de dinâmicas urbanas e naturais e roteiros gastronômicos.

Um outro tipo de interação que deve ser considerado é o translado pelo modal rodoviário. Muitos passageiros optam por fazer parcialmente o deslocamento de ônibus e depois seguir um trecho maior de avião. Cidades fronteiriças possibilitam tal prática, inclusive com ônibus semi-urbanos, como Foz do Iguaçu-Puerto Iguazu, Vila PortesPuerto Iguazu, Paso de los Libres-Uruguaiana. Existem outras linhas rodoviárias internacionais de ônibus regulares, como as operadas pela Flechabus e JBL. Geralmente, as principais partem de cidades como Rio de Janeiro-RJ, São Paulo-SP, Foz do Iguaçu-PR, Balneário Camboriú-SC e Florianópolis-SC para Buenos Aires, Florianópolis-Posadas, Córdoba-Balneário Camboriú e Florianópolis-Salta. Todavia, o movimento de turistas que viajam entre os dois países com veículos particulares também deve ser avaliado.

Outras situações acerca da interação aéreo e rodoviário também precisam ser examinadas. Destinos turísticos que não contam com a prestação de serviço aéreo são atendidos pela extensão terrestre. Seja o caso de Balneário Camboriú-SC entre os aeroportos de Navegantes-SC e Florianópolis-SC como o destacado em Rodrigues (2020), ou algumas cidades da Região dos Lagos no Rio de Janeiro.

Em resumo, pode-se dizer que o Brasil, por suas condições geográficas, apresenta opções bastante favoráveis à prática do turismo, desde o litorâneo aos roteiros urbanos, ao passo que a Argentina apresenta uma geografia diferente, a começar pela Cordilheira dos Andes e a Patagônia. Sobre o mundo dos negócios, sobretudo aquelas dinâmicas já destacadas por Silva (2018), elucida também a conectividade pela circulação empresarial entre esses países. Todavia, a crise provocada pelo novo coronavírus põe em xeque tais dinâmicas, e possivelmente implicará a inserção de novas estratégias no setor aéreo.

\section{Considerações finais}

Os sistemas de engenharia e os fluxos expressam novas formas de interações e integrações no mundo globalizado, ao mesmo tempo que acirram a competitividade territorial. Os impérios da fluidez criam seletividades e posteriormente uma especulação do espaço. Portanto, a realidade exposta pelos fluxos aéreos de passageiros evidencia as redes de circulação que condizem com diferentes dinâmicas regionais.

O objetivo deste texto foi de analisar as estratégias competitivas das empresas aéreas na recente reestruturação do setor e a topologia dos. Fica evidente que a remodelação da logística corporativa contribuiu para uma modificação considerável na tipologia dos fluxos aéreos de passageiros entre o Brasil e a Argentina.

A refuncionalização dos objetos a partir da interação de novos processos expressa o jogo da competitividade, e lhes atribui novas funções, cada vez mais dotadas de fluidez. Neste trabalho, fica evidente que as grandes corporações estão cada vez mais presentes nas escalas locais. A seletividade territorial expressa não apenas a desigualdade, como também o jogo de poder que envolve a atuação da logística de Estado e a corporativa. 
Diante disso, deve-se considerar a historicidade da constituição das redes geográficas de circulação como um elo de compreensão do presente. Pensar e repensar que as relações de poder refletem essa realidade, sobretudo aquelas que estão interligadas aos meios transportes, obedecendo a uma lógica histórica, hierárquica e desigual, e, por conseguinte, acabam por intensificar a diferenciação espacial entre os lugares.

A lógica de poder das grandes empresas faz do território um jogo de xadrez. Cada uma delas possui suas peças e, para movimentá-las, é preciso traçar suas próprias estratégias com o que se tem em jogo, lembrando que cada uma possui uma função e uma forma de atuar. Entretanto, o objetivo é o mesmo: ampliar a acumulação de capital. No final das contas, o que deve ser considerado são os impactos na organização territorial

Ao observar a variação das operações das empresas aéreas entre o Brasil e a Argentina, há de se levar em conta a intensa competitividade entre companhias de diferentes nichos, das quais as brasileiras assumem uma maior soberania, seguidas das argentinas e depois de demais estrangeiras, sobretudo europeias, nas operações entre o Brasil e a Argentina.

O processo de formação espacial de ambos os países elucida as dinâmicas territoriais. O turismo é o ponto crucial presente no Brasil e na Argentina, o que acelera essas interações e constitui novas redes de circulação. $\mathrm{O}$ efeito multiplicador por trás da aviação e do turismo é fundamental para a configuração a divisão territorial do trabalho.

Sobre a evolução dos pares dialéticos de origem-destino, verifica-se cada vez mais a intensificação da centralidade dos voos entre os hubs. Os destinos, na sua maioria, envolvem dinâmicas turísticas. Todavia, não se deve ausentar o papel do fluxo de negócios e do empresariado entre os dois países.

Como já foi ressaltado, não necessariamente o passageiro desembarca em GuarulhosSP ou Campinas-SP e vice-versa. As estratégias logísticas das companhias aéreas em adotar o sistema de $h u b$ colabora para um melhor aproveitamento de suas rotas. Claro que cada empresa tem seu modo de atuar, mas aqueles voos que se destinam às cidades brasileiras do litoral dificilmente terão conexões, isto é, o passageiro objetiva o desembarque ali mesmo. No território argentino, os destinos são as principais cidades do país.

Há um fluxo de retorno em ambos os países. Não se pode desconsiderar que apenas passageiros que embarcaram em Confins-BH e Brasília-DF irão desembarcar em Ezeiza, uma vez que se trata de hubs. Embora o passageiro argentino busque atividades laborais no litoral brasileiro, há outros que buscam outras formas diferenciadas que sejam fora da costa. Da mesma forma, o turista brasileiro busca os circuitos dos Andes ou na Patagônia, assim como roteiros culturais e urbanos, como aqueles proporcionadas por Buenos Aires.

O setor apresentava uma franca expansão e tendência de crescimento. Porém, os impactos da pandemia ainda são incalculáveis. Ao mesmo tempo em que a crise afeta o setor aéreo, as economias locais encontram-se fragilizadas, haja vista que, no caso brasileiro, trata-se de um Estado negacionista e improvidente, e, no argentino, uma tentativa de retomada de crescimento após um fracasso neoliberal.

A compreensão dessas redes de circulação carece de atenção na ciência geográfica. Deve-se considerar que os meios de transporte são elementos fundamentais para a organização territorial, logo são indispensáveis de análise. O setor aéreo exprime não apenas um retrato das dinâmicas socioeconômicas nos territórios envolvidos, mas também uma multiplicidade de elementos que contribuem para a circulação de pessoas, mercadorias, capital e informações. 
Portanto, alguns pontos correlacionados com turismo e transporte aéreo podem ser aprofundados em eventuais pesquisas, sobretudo aquelas que tratam das dinâmicas regionais e urbanas e estão atreladas ao par de origem-destino dos voos. A movimentação via modais terrestres ou outras formas de complementaridade que outros passageiros utilizam para se deslocar entre os países também surgem como um tema a ser investigado.

Este trabalho buscou traçar alguns pontos confluentes que dizem respeito ao território, circulação e meios de transporte. Também se tratou das principais estratégias logísticas adotadas para o crescimento do setor aéreo que integra, em parte, o Brasil e a Argentina. Por fim, os fluxos aéreos de passageiros elucidam uma franca expansão, parada pela pandemia em 2020, mas que retratam uma infinidade de interações espaciais que carecem de ser exploradas pela ciência geográfica. 


\section{Q Bibliografia}

" ANAC (2020). Dados Estatísticos. [online] Available at: <https://www.anac. gov.br/assuntos/dados-e-estatisticas/dados-estatisticos/arquivos/dadosestatisticos.csv> [Accessed 11 octuber 2020].

» Aredes, A. y Silveira, M. R. (2011) Transporte aéreo e produção de novas territorializações na disputa pela demanda turística. En: Silveira, M. R. (org). Circulação, Transportes e Logística: diferentes perspectivas (p. 21-67). 1ed. São Paulo: Outras Expressões.

" Arroyo, M. (2015). Redes e circulação no uso e controle do território. En: M. Arroyo e R. de C. A. da C. (orgs) Território e Circulação: a dinâmica contraditória da globalização. FAPESP/PPGH/CAPES/Annablume.

»Bielschowsky, R. (2013). Estratégia de desenvolvimento e as três frentes de expansão no Brasil: um desenho conceitual (Texto para Discussão, n. 1828). Rio de Janeiro: Ipea.

» BLANCO, J. (2015) Territorio, circulación y redes: articulaciones y tensiones. En: M. Arroyo e R. de C. A. da C. (orgs) Território e Circulação: a dinâmica contraditória da globalização. FAPESP/PPGH/CAPES/Annablume.

"Brandão, C. (2019). Mudanças produtivas e econômicas e reconfiguração territorial no Brasil no início do século XXI. Revista Brasileira de Estudos Urbanos e Regionais, São Paulo, v. 21, n. 2, p. 258-279.

»Corrêa, R. L. (1987). Região e organização espacial. São Paulo: 3. ed. Editora Ática S.A.

»Corrêa, R. L. (2006). Estudos sobre a rede urbana. Rio de Janeiro: Bertrand Brasil.

»Corrêa, R. L. (2018) Caminhos paralelos e entrecruzados. São Paulo: Editora Unesp.

»Pons, J. M. S. y Reynés, M. R. M. (2004). Geografía de los transportes. Imprenta [Palma de Mallorca]: Universitat de les Illes Balears.

"Porter, M. (1986) Estratégia competitiva: técnicas para análise de indústrias e concorrência. Rio de Janeiro: Campus.

» RAFFESTIN, C. (1993). Por uma geografia do poder. São Paulo: Ática.

»Rangel, I. (2005). Obras Reunidas (dois volumes), organizador: César Benjamin, Rio de Janeiro: Contraponto.

»Rodrigues, L. A. (2020). Transporte aéreo de passageiros em Santa Catarina: estratégias logísticas e organização territorial. Dissertação em Geografia Universidade Federal de Santa Catarina, Florianópolis. Disponible en: <https:// repositorio.ufsc.br/handle/123456789/215848>.

»Santos, M. (1977). Sociedade e Espaço: a formação social como teoria e como método. In: Boletim Paulista de Geografia, São Paulo 54, 81-99.

"Santos, M. (2014). O espaço dividido: os dois circuitos da economia urbana dos países subdesenvolvidos. - $2^{\underline{a}}$ ed.- São Paulo: Editora da Universidade de São Paulo.

» Santos, M. (2017). A natureza do espaço. Técnica e tempo, razão e emoção. São Paulo: Edusp. 
» Silva, A. O. (2017). Território, internacionalização e integração regional: as empresas no contexto da relação argentino-brasileira. Dissertação de Mestrado, Faculdade de Filosofia, Letras e Ciências Humanas, Universidade de São Paulo, São Paulo.

» Silveira, M. R. (2011). Geografia da Circulação, Transportes e Logística: Construção epistemológica e perspectivas. In M. R. Silveira (org.). Circulação, transportes e logística. Diferentes perspectivas (21-68). São Paulo: Expressão Popular.

»Silveira, M. R. (2019). Circulação, transporte e logística e seus impactos na fluidez e na competitividade territorial no Brasil. In M. R. Silveira e N. F. Felipe Junior (Ed). Circulação, Transporte e Logística no Brasil. Florianópolis: Insular.

» Silveira, M. R. y Rodrigues, L. A. (2020) Reestruturação do transporte aéreo de passageiros em Santa Catarina: da aviação regional para o sistema de hub, GEOUSP Espaço e Tempo (Online), 24(3), p. 444-467.

"Singer, A. (2015) Cutucando onças com varas curtas. Novos Estudos, CEBRAP, p. 23-40.

» Swyngedouw, E. (2018). Globalização ou glocalização? Redes, territórios e reescalonamento. En: Brandão, C. A. et al. (orgs) Escalas espaciais, reescalonamentos e estatalidades: lições e desafios para América Latina. (p.71106) Rio de Janeiro: Letra Capital.

\section{Lucas Azeredo Rodrigues / lucas.azeredo.rodrigues@gmail.com}

Licenciado em Geografia (UFFS/Chapecó-SC). Mestre e doutorando em Geografia pelo Programa de Pós-Graduação em Geografia da Universidade Federal de Santa Catarina (PPGG-UFSC). Membro do Grupo de Estudos sobre Dinâmicas Regionais e Infraestruturas (GEDRI-CNPq), Laboratório de Estudos sobre Circulação, Transporte e Logística (LabCit-UFSC), Núcleo de Estudos sobre Transporte (NETRANS-Unila) e do Grupo de Estudos sobre Transporte UrbanoRegional (GETUR). 